\title{
Effects of Leasehold on Community Forest Association Benefits in Dryland Resources Management: A Case Study of Kibwezi Forest in Kenya
}

\author{
John Mwendwa Mugambi ${ }^{1^{*}}$, Jane Kagendo ${ }^{1}$, Mulaha Kweyu ${ }^{2}$ \\ and Musingo Tito E. Mbuvi ${ }^{3}$ \\ ${ }^{1}$ School of Social Sciences, Mount Kenya University, Kenya. \\ ${ }^{2}$ School of Social Sciences, Kenyatta University, Kenya. \\ ${ }^{3}$ Principal Research Scientist Kenya Forest Research Institute, Kenya.
}

Authors' contributions

This work was carried out in collaboration among all authors. Author JMM designed the study, performed the statistical analysis, wrote the protocol and wrote the first draft of the manuscript. Authors JK and MK guided the study. Author MTEM read and suggested necessary changes. All authors read and approved the final manuscript.

Article Information

DOI:10.9734/AJGR/2020/v3i330109

Editor(s):

(1) Dr. Jephias Mapuva, Bindura University of Science Education, Zimbabwe.

Reviewers:

(1) Romeet Saha, Forest Research Institute, India. (2) Diego Ribeiro de Aguiar Manejo de Ecossistemas, Universidade Federal do Oeste do Pará, Brazil (3) José Oliveira Dantas, Instituto Federal de Sergipe - Campus São Cristóvão, Brazil. Complete Peer review History: http://www.sdiarticle4.com/review-history/58646

Original Research Article

Received 02 May 2020

Accepted 08 July 2020

Published 18 July 2020

\section{ABSTRACT}

Aims: The aim of this paper was to investigate whether community forest association (CFA) get benefits as they conserve dryland forest that is also fully leased.

Study Design: The paper adapted descriptive survey design. Both descriptive and inferential statistics were used.

Place and Duration of Study: The study was conducted between the year 2018 December and 2020 January in Kibwezi forest.

Methodology: This study included 139 individuals who were issued with questionnaires (household survey) and 5 officials from forest department who were interviewed. 
Results: The questionnaires response rate was 96\% since 134 questionnaires out 139 were returned. The introduction of leasehold significantly reduced benefits community forest association used to get. There is no significant association between being a member of Community Forest Association and getting employment in dryland forest conservation sinceChi square results were; $x^{2}$ $=3.953$, $\mathrm{df}=3, P=.267$.

Conclusion: There is no special benefit the Community Forest Association gets from conservation of Kibwezi forest. For community to participate in forest management that have been leased there should be incentives. In fully leased forest, community forest members should jointly work with Kenya Forest Service as per the Participatory Forest Management. To get desired results of community forest participation in dryland, different actors should come up with innovative ways of conferring benefits to the Community Forest Association and compel the lessee to adhere to the legal requirement of continued access of benefits to the communities as it was before the lease.

Keywords: Participatory forest management; lessee; lease; benefits; forest dwellers; conservation; community and stakeholders.

\section{ABBREVIATIONS}

Community forest- These are people living next to the forest or have interest in it. They may be around about five kilometers from forest edge or more as long as they have special interest with particular forest.

\section{CFA - Community Forest Association. \\ FAO - Food and Agriculture Organization. \\ FLR - Forest Landscape Restoration \\ GoK - Government of Kenya. \\ KFS - Kenya Forest Service. \\ NACOSTI -National Commission for Science, Technology and Innovation. \\ PFM -Participatory Forest Management.}

\section{INTRODUCTION}

\subsection{Background of Study}

Due to degradation of dryland forest globally, Participatory Forest Management (PFM) was introduced to protect and regenerate forest as they share the benefits [1]. Countries like Nepal have very successful PFM due to their long experience involving adjacent communities in forest management. Nepal, degradation of forest reduced significantly when communities were allowed to own, manage and guard forest [2]. For African forest to be restored, there is need for urgent actions to be taken by all countries [3]. These actions should include participation of community forest dwellers in forest conservation and management. For the status of dryland forest to improve, community forest should be involved in forest management since they are more connected to the realities on the ground than any government institutions [4]. The community should be included in all levels of PFM which include formulation of law, planning, implementation, monitoring and evaluation [5]. Prevention of deforestation and increasing area under the forest in the world will reduce potential consequences of deforestation such as global warming, loss of livelihoods among others [6]. Although PFM is one of solutions of forest degradation, there are very few nations where it operates optimally. Against this background, this research paper was written to investigate activities and benefits community get from dryland forest conservation that is fully leased.

\subsection{Problem Addressed in This Study}

Globally, drylands degradation has led to rethinking of protection strategies of forest management [7]. In South America, forest was degraded to unimaginable levels hence community participation was proposed [8]. For community to participate well, direct benefits to community members should exceed cost [9]. In South America, participation of community significantly reduced benefit accrued since they could not graze animals in the forest nor get other forest products [8]. Although dryland forest are important ecosystems, application of Forest landscape restoration (FLR) has received relatively low attention. FLR seek to restore ecosystems while conferring benefits to forest dwellers [7]. Due to perception that people get little benefits from drylands forests as compared to other types, there is less participation and sometimes no community participation [10]. In Chile, it was found that community had little impetus to participate in dryland PFM since direct benefits were insignificant [11]. Although dryland contain most threatened biomes, very little 
attention has been drawn hence need for comprehensive research worldwide [12].

In Africa, most of the dryland forest have been degraded due to grazing, logging and clearance for farming [13]. In African nations, the highest deforestation has occurred in drylands forests as people around them use firewood to get energy in their households due to lack of alternative livelihoods [14]. In Ethiopia, dryland forest has received less attention compared to other types of the forest [6]. To make sure that all parts of African nations have adequate forest cover, there is need for research on how community can be involved in management of drylands forest.

Kenyan constitution 2010 recommends that more than $10 \%$ of total land area of the nation should be covered by forest. However, this has not been achieved and forest degradation has continued. Community Forest Association (CFA) was constituted to improve the forest management. Despite the presence of CFA, several forest have been degraded. The situation in Makueni County is not different from other parts of Kenya where forest cover remains relatively low. Kibwezi forest cover is four times less than constitutional recommendation of $10 \%$ hence need to conduct research on how to conserve remaining forest. Kibwezi forest and its community forest association; Kibwezi Forest Association (KICOFA) were taken as the study case.

Kibwezi Forest Association was formed in the year 2012 in order to jointly participate in the management of the forest through Participatory Forest Management (PFM). The association had 246 registered members. Members registration fees was one hundred Kenyan shillings (1US \$) per member. Each member had to contribute fifty Kenyan shilling ( 0.5 US \$) per month to run activities of the CFA.

Since the formation of the CFA, there is little that is known on benefits community get by participating in dryland resource management. The study would specifically enrich the understanding of the subject of forest management on participation of community in dryland forests and also in fully a leased forest.

\subsection{Literature Survey}

Globally, more than 1.5 billion people have benefited from the forest resources as they participate in decision making and forest management especially in mountain forest [11].
The involvement of forest dwellers in management of forest brought benefits to people living in environs. In India, Mendha Lekha community was given legal rights to manage the forest in 2009 including being allowed to manage bamboo forest. This led to making a profit of USD 150,000 between 2011-2014 that was used to develop the area [3]. The community participates in forest conservation if the benefits exceed cost; the participation lead to improvement of their lives. These benefits may be direct or indirect. Joint business ventures may be one of these benefits that can motivate conservation where the community work in partnership for mutual benefits [11]. More than two billion people depend on dryland forest to get pasture, food and livelihood hence making this type of forest very important in global skills [3] Although India has one of the best models of community participation in forest management, there are very few individuals benefits hence low morale among vast majority of community forest [15].

In Africa, Cameroon, Gabon and Equatorial Guinea have crafted laws that allows communities to benefit from forest as they manage. These laws allow all the members of community forest who participate in forest management get direct benefits from forest resources. These benefits act as incentives to participate in PFM [15]. In Ghana, people participation in forest management was directly proportional to the benefits they received directly [16]. In developing countries, forest products accounts more than $20 \%$ income of people living in rural areas [3]. In West Africa, more than $26 \%$ of the total income of the household income is contributed by forest products income [17]. In Ethiopia, members of community forest were allowed to graze their cattle in the dryland forest these was considered as a benefit they enjoyed as a result of participation in PFM [15].

Regionally, in Mozambique and Uganda, deforestation has been associated with poverty. Most of the people who degrade forest do so because they need materials which they cannot get through legal method due to poverty hence degrading the forest [3]. If the livelihood of community forest is taken care of, there is possibility that the forest degradation is going to reduce. The forest can be used sustainably to improve the livelihood of the communities hence becoming blessing to the community [17]. In Congo, people living near forest had destroyed forest until the government involved them in 
management of the forest. When adjacent communities were in involved in PFM, forest destruction reduced significantly since their livelihood was well taken care of [13]. The dryland forest provides alternative source of income to the farmers living near forest when the rain fails for a period of time; this may as well pose danger to the forest. When communities living near the forest perceive to be part of forest management, they guard the forest against all the forces of destruction [15]. In South Ethiopia, dry land forest contributed to about $63 \%$ of poor families' income. Low income earners were able to get their livelihoods from selling different forest products without compromising status of the forest [18]. In Madagascar, it was found that no boundary could deter people from destruction of forest if community forest livelihood were not addressed. All legal channels that were employed failed to stop destruction of forest since people had no livelihood. When the livelihoods were addressed, the forest was well protected by the community as part of their resources [19]. In Ethiopia, fair distribution of benefits from sale of forest product increased probability of community participation in PFM [18]. The level of participation in PFM was directly proportional to perceived benefits people received from forest management [9].

In Kenya, more community benefits have been incorporated in law to encourage community participation for instance, adjacent community participate in Income Generating Activities (IGAs) [20]. The Forest Conservation and Management Act, 2016, recommend the following income generating activities: Grass collecting, ecotourism, recreation activities, plantation establishment schemes, grazing, honey harvesting among others as long as they do not contradict conservation effort [21]. The people near the forest should gain benefits from forest directly and indirectly as they participate in forest management [22]. Although the law recommends several benefits, there has been no way of catering for different realities in different forest. Some forest, especially those found in dry areas have conditions which cannot support some of benefits prescribed by law. There is no recommendation that can cut across all types of forest in Kenya [23]. The community is motivated to participate in forest governance if the benefits of PFM exceeded the cost [9]. Community participation in major water towers have benefits ranging from growing crops, getting fund from selling of trees in Plantation Establishment and Livelihood schemes (PELIS), harvesting water among others. These benefits acts as incentives for forest dwellers to participate in conservation of major water towers [24]. The community can only participate in forest management if they share direct benefits that act as incentive for participation. The level of participation is directly proportional to the expected benefits [9].

\subsection{Justification for This Study}

Most of the previous researchers on CFA benefits have concentrated on mountainous forest due to its perceived benefits over other forests. There is little information available on how the community benefits if they participate in dryland forest under leasehold. Since there is no recommendation that fits all situations of forest governance, there was need to do research in drylands of Kibwezi forest to complement effort done by previous researchers [25]. Kibwezi forest is one of dry forests located in a County with little forest cover. There is limited literature of CFA activities in dryland forests in Kenya that has an existing forest management agreement with the CFA and that has been fully leased to another entity.

\section{METHODOLOGY}

This study adapted descriptive survey design in order to meet all the research objectives. This design is suitable to describe current status of forest. Descriptive research is very useful in describing current status of the forest research. The study was carried between December 2018 and January 2020. The data was collected using questionnaires and interview schedule. The research design is a master plan that clearly outline specific procedures and methods of data collection and analysis [26]. Based on this, research design the study attempted to seek responses to questions by assessing specific objectives relating community participation that influenced dryland resource management.

\subsection{Location of the Study}

Kibwezi forest is located in semi-arid region in Makueni county. The altitude ranges from 9001015 metres above sea level. Underground Umani springs passes through the forest and spring out in Kibwezi town. The area receives a mean annual rainfall of 250-350 mm per year. Kibwezi area receives bimodal rainfall due to its proximity to Equator. It receives short rains 
between November and December while long rains are experienced between March and April. The area has moisture indices of $32 \%$. February and October are the hottest months while July is the coolest [26].

Kibwezi Sub County has a population of 248,704 people, distributed over an area of 52,979 square kilometres hence sparsely populated. The area has sixty-two persons per square kilometre [26].
The people around forest are farmers, artists and traders. The area is categorised as agropastoralism since crop farming and animal keeping are dominant economic activities. They keep domestic animals such as cows, goats, hens and sheep. Some people do wood curving for commercial purpose. Farmers comprises $78 \%$ of the residents, mostly undertaking subsistence farming of beans and maize. Only $10 \%$ of the residents have formal employment while $12 \%$ are self-employed [26].

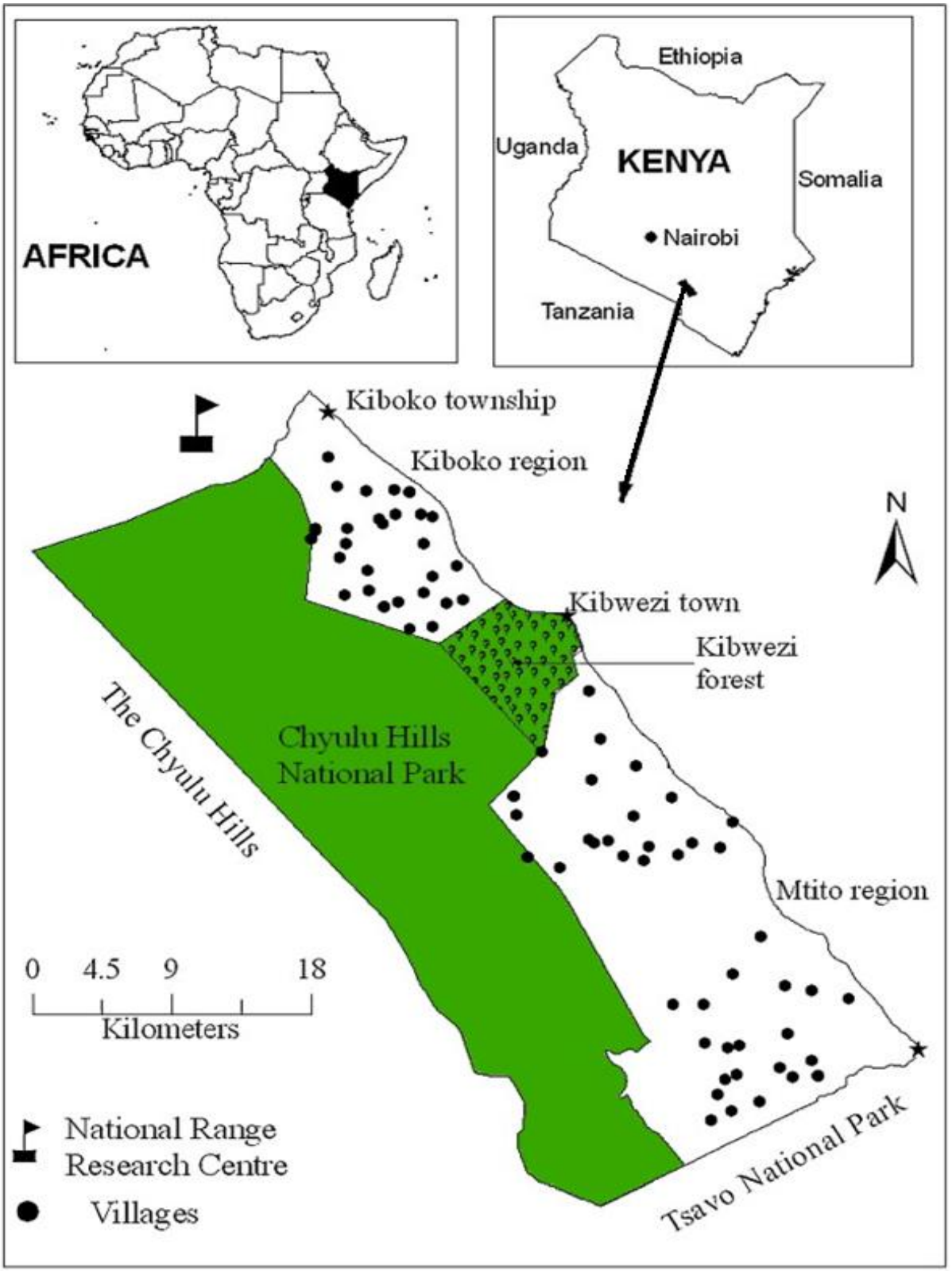

Fig. 1. Kibwezi forest map (study location)

Source: David Sheldrick 2020 


\subsubsection{History of Kibwezi forest}

Kibwezi forest was gazetted in 1936 as a protected area. The forest is 5849.6 hectares. David Sheldrick Wildlife trust was given thirty years' concession to conserve and maintain bio diversity. The concession includes management of natural resources, anti-poaching patrols, construction of electric fence while safeguarding local communities' livelihoods [27].

\subsection{Target Population}

The researcher targeted community forest and government workers working in Kibwezi forest and also Kibwezi forest area. Kibwezi forest cover was also targeted to enumerate changes that may have been caused by community actions. Sampling units was 2,585 households from Mikuyuni location, in Kibwezi Sub-County and Kibwezi forest cover. A sampling unit can be defined as a village or geographical area or individuals. Target population is all people or items that are considered in a study [26].

\subsection{Sampling Procedures and Techniques}

The researcher used purposive sampling to identify members of CFA, later snowballing was used to locate others members. Random sampling was used to identify non CFA members. The data from this category was collected using questionnaires administered to households. Quantitative methods are suitable for collecting data from sample population using closed ended questions [26].

Purposive sampling was used to identify forest employees to be interviewed. Officials from KFS, KEFRI and KFS rangers were identified and interviewed. The data from this category was collected using interview method. Qualitative methods are suitable to collect data from institutions heads since it uses open ended questions [26].

\subsection{Sample Population}

Mugenda and Mugenda proposed the following formulae to compute the sample size of population of less than ten thousand [28].

$$
n=\left(z^{2} p q\right) / d^{2}
$$

Where

$$
n=\text { desired sample size }
$$

$$
\begin{aligned}
& z=\text { standard normal deviation }(1.96) \text { for } 95 \% \\
& \text { confidence level } \\
& p=\text { expected reverence of proportion }(10 \% \text { is } \\
& \text { recommended hence } 0.1) \\
& q=1-p \text { therefore } q=(1.0-0.1=0.9) \\
& d=\text { statistical significance }(0.5) \\
& n=\left(1.96^{2} \times 0.1 \times 0.9\right) \div 0.5^{2}=139 \text {. }
\end{aligned}
$$

A total of 139 respondents were issued with questionnaires. Out of 139, there were 77 members of CFA while 62 were non-members of CFA. Only 134 who responded our Questionnaires. Out of 76 CFA members who responded to our questionnaires, 32 were from Kithasyiu area, 18 were from Kaunguni while 16 were from Mikuyuni. Out of 58 non CFA members who responded to our questionnaires, 21 were from Kithasyiu area, 20 were from Kaunguni while 17 were from Mikuyuni.

\subsection{Validity and Reliability of Instruments}

Pre-testing of questionnaires was done to ensure content validity. The pre-testing was carried in Utithi location. Fourteen questionnaires were distributed. The questionnaires from pretesting were analysed using Pierson correlation between the questionnaires given to the same persons to fill with two weeks' interval. A correlation coefficient of 0.72 was found. The instrument was reliable since it is recommended a correlation coefficient of more than 7.0 in a test retest method [26].

\section{RESULTS AND DISCUSSION}

The following were the results and findings of this research;

\subsection{Reason for Community Participation in Forest Management}

When members of community forest were asked the reasons why they participated in forest management they enumerated many reasons as outlined in Table 1. It is evident that majority of members of community forest were driven by benefits they access from forest conservation practices. About $61 \%$ of the members participated so that they are allowed to get forest product for their direct or indirect consumption. About $61 \%$ were hopeful that they will benefit from donor funds. About $43 \%$ had hopes that participation in forest management will give them advantage when there is a vacancy in forest department. Although these were their expectation, the key informants were opined that 
Table 1. Incentives to participate in forest management

\begin{tabular}{|c|c|c|c|c|c|}
\hline $\begin{array}{l}\text { Ranking } \\
\text { participation(where } 5 \text { is } \\
\text { highest and } 1 \text { is lowest) (\%) }\end{array}$ & $\begin{array}{l}1 \\
(\%)\end{array}$ & $\begin{array}{l}2 \\
(\%)\end{array}$ & $\begin{array}{l}3 \\
(\%)\end{array}$ & $\begin{array}{l}4 \\
(\%)\end{array}$ & $\begin{array}{l}5 \\
(\%)\end{array}$ \\
\hline $\begin{array}{l}\text { To access forest products like } \\
\text { firewood, grazing land etc. }\end{array}$ & $\begin{array}{l}42 \\
(31.3 \%)\end{array}$ & $\begin{array}{l}42 \\
(30.6 \%)\end{array}$ & $\begin{array}{l}22 \\
(16.4 \%)\end{array}$ & $\begin{array}{l}21 \\
(15.7 \%)\end{array}$ & $\begin{array}{l}8 \\
(6.0 \%) \\
\end{array}$ \\
\hline $\begin{array}{l}\text { To get benefits that were } \\
\text { promised to community forest } \\
\text { members eg payment }\end{array}$ & $\begin{array}{l}49 \\
(36.6 \%)\end{array}$ & $\begin{array}{l}33 \\
(24.6 \%)\end{array}$ & $\begin{array}{l}29 \\
(21.6 \%)\end{array}$ & $\begin{array}{l}21 \\
(15.7 \%)\end{array}$ & $\begin{array}{l}2 \\
(1.5 \%)\end{array}$ \\
\hline $\begin{array}{l}\text { Access benefits from donors } \\
\text { funds }\end{array}$ & $\begin{array}{l}22 \\
(16.4 \%) \\
\end{array}$ & $\begin{array}{l}41 \\
(30.6 \%) \\
\end{array}$ & $\begin{array}{l}32 \\
(23.9 \%)\end{array}$ & $\begin{array}{l}23 \\
(17.2 \%)\end{array}$ & $\begin{array}{l}16 \\
(11.9 \%)\end{array}$ \\
\hline $\begin{array}{l}\text { To reduce the destruction of } \\
\text { the forest }\end{array}$ & $\begin{array}{l}14 \\
(10.4 \%)\end{array}$ & $\begin{array}{l}29 \\
(21.6 \%)\end{array}$ & $\begin{array}{l}41 \\
(30.6 \%)\end{array}$ & $\begin{array}{l}25 \\
(18.7 \%)\end{array}$ & $\begin{array}{l}25 \\
(18.7 \%)\end{array}$ \\
\hline $\begin{array}{l}\text { Get privileges like being hired } \\
\text { if there is job opportunities }\end{array}$ & $\begin{array}{l}26 \\
(19.4 \%)\end{array}$ & $\begin{array}{l}31 \\
(23.1)\end{array}$ & $\begin{array}{l}24 \\
(17.9 \%)\end{array}$ & $\begin{array}{l}27 \\
(20.0 \%)\end{array}$ & $\begin{array}{l}26 \\
(19.4 \%)\end{array}$ \\
\hline
\end{tabular}

most of their expectation could not be met since they are not sustainable and were based on misconception. The findings were not consistent with Mbuvi, 2018 findings who found out that PFM as decentralized system of forest governance improve the livelihoods of Community Forest Association members [25]. There is need for stakeholders to consider how members of given community shall benefit when crafting policies for PFM.

As the benefits that were promised during the inception of KICOFA reduced, the number of active members reduced. Involvement of investor in forest concession tremendously reduced anticipated benefit the community anticipated such as grazing in forest, getting wood, and selling forest products. This was attributed to fencing of forest and limiting any movement in the forest without permission from investor. Some members have forest based enterprises such as seedling planting. Members of CFA sell their seedling individually since there is no organization. Most of the people who had nurseries for generating income had low levels of education. Seedling planting was done as a means of livelihood.

Members of community had equal chances of getting services like employment from the forest department and David Sheldrick Trust whenever vacancies arise regardless of PFM membership status. There is no preferential treatment of members and non-members when vacancy arises in forest department. Most of the members of community found no impetus to participate since there was no extra benefit for members of CFA. These findings explain why the number of the members of CFA were reducing from 246 to
101 instead of more members joining the group. Members of community forest were of opinion that the level of participation should be compensated by the getting more benefits. The more the direct benefit, the higher the chances of participation.

Some of the benefits community should enjoy were curtailed by the presence of investor (lessee) who fenced the forest under concession hence the community has no access to Kibwezi forest. Data from key informants shows that benefits such as grazing, getting herbs for medicinal purpose were no longer attainable after establishment of electric fence. Before the concession, members of the society were allowed to graze cattle in the forest in line with Kenyan law which gives the community some rights such as grazing among others. These findings agree with (Bekele, et al., 2016) who concluded that involvement of multinational investors reduces the benefits that community get from PFM [15].

\subsection{Benefits of Community Forest Association from Conservation of Kibwezi Forest}

The study established that the following were the benefits of community forests derived from conservation of Kibwezi forests. These benefits were:

\subsubsection{Creation of job opportunities}

Although the researcher was not able to determine exact number of the workers who came from CFA, David Sheldrick Trust has employed several people from the locality to take care of forest and coordinate ecotourism 
activities. Twelve scout were employed directly from CFA during the inception of forest rejuvenation by David Sheldrick Trust through KFS. Initially Kibwezi scouts worked on behalf of CFA but lacked money to pay and facilitate their activities. Members of community were employed as casuals and others on permanent terms depending with qualification and availability of vacancies.

'KFS does not employ members of CFA but in our concession agreement with David Sheldrick Trust, members of CFA were to be employed and given any job where possible. The twelve scouts that previously worked with CFA were employed by Trust. For anybody to be employed, academic qualifications are key consideration."

To verify if there was any relationship between being a member of KICOFA and getting employment in forest department, Chi square was done and the results were $x^{2}=3.953$, $d f=3$, $\mathrm{P}=.267$. Since the $\mathrm{P}$-value is more than 0.05 , we conclusion that, there is no significant association between being a member of Community Forest Association and getting employment in dryland forest conservation. When some employment opportunities arise in forest department, all members of the community have equal chances of being employed. There was no preferential treatment available for members of CFA. Being a member of CFA was not added advantage

\subsubsection{Forest based enterprise}

Several households had established tree nurseries. These trees are sold by individual farmer. Members of CFA get capacity building by the KFS and KEFRI on the best methods of establishing nurseries and identification of trees species that are more viable in the area.

Most of the community members in Kibwezi participated in honey harvesting 45 (34\%). The presence of forest presents good condition for honey harvesting. Grazing on the forest was benefit the community enjoyed before the fencing of Kibwezi forest 33 (25\%). Only 23 (17\%) were involved in collection of firewood from the forest before it was fenced. About $16 \%$ of the respondents participated in recreation activities which give them livelihood. Only $9 \%$ had participated in ecotourism as source of livelihood. All these activities are not centrally managed by CFA is no longer sustainable due to lack of finance and registration status.

\subsubsection{Provision of water}

Among respondents, $46.3 \%$ had piped water in their homestead from Umani water project while $53.7 \%$ had no piped water. The Kibwezi community benefit through Umani water project that has benefited a section of the area. There are some few individuals who are against the project. Majority of the people who oppose Umani water project were from Kaunguni area which had not benefited Umani water project due to its geographical positioning.

Fig. 2 highlights opinion of respondents interviewed as follows; $35.8 \%$ strongly agreed that there was nothing wrong with taping water from forest for domestic use while $35.8 \%$ agreed with the same. However, $28.4 \%$ were opined that drawing such amount of water in the forest may lead to problems in future. Minority who views were consistent with (Kiringe, Mwaura, \&Warinwa, 2016) who found that Kibwezi river levels were reducing at alarming rate [26]. The dissenting voices are opined that drawing large amount of water was responsible for drying of rivers in the vicinity. The key informants dismissed this argument because all the legal procedures were followed during the inception of water projects. The members of the community forest benefited through getting piped water in an area with an acute water shortage. Due to dryness of the area, members without piped water walk for very long distance to fetch water for domestic use. Being connected to piped water was not dependent on if one was a member of CFA or not.

Table 2. IGAs in Kibwezi forest

\begin{tabular}{lll}
\hline Availabilities of IGAs & Number & Percent \% \\
\hline Firewood collection & 23 & 17.16 \\
Ecotourism & 12 & 8.96 \\
Grazing & 33 & 24.66 \\
Recreation activities (eg Dancers) & 21 & 15.67 \\
Honey harvesting & 45 & 33.58 \\
Total & 134 & 100 \\
\hline
\end{tabular}




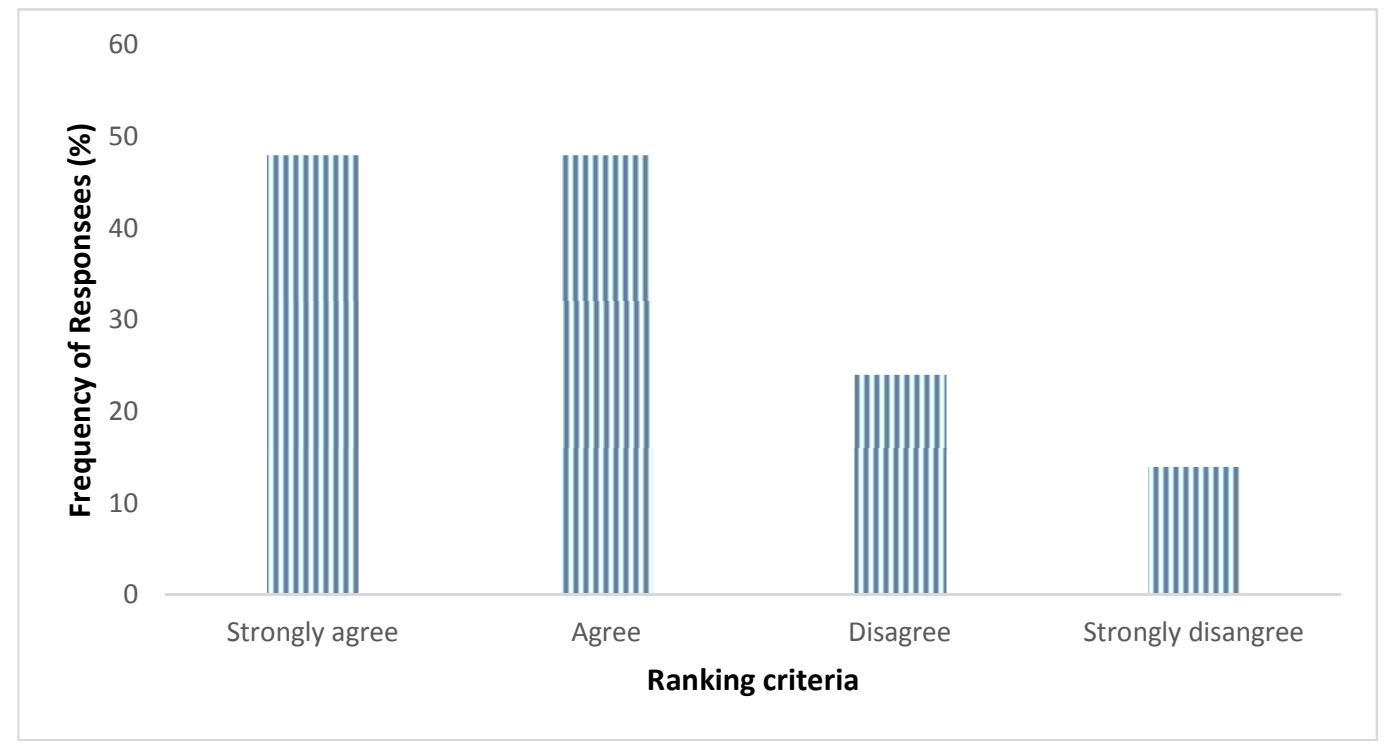

Fig. 2. Taping Water from Kibwezi Forest Source: Field Data (2020)

\subsubsection{Collecting soil for nurseries}

Members of the group were allowed to collect soil from Kibwezi forest for nursery establishment. Forest soil increases the survival rate of seedlings since the soil is fertile.

'When members of the community request to be given soil for planting seedling, they are granted permission. Members of CFA are supervised as they collect soil to make sure that they do not do anything that is not authorised."

The soil collected from Kibwezi forest is very fertile hence good for planting seedlings.

\section{CONCLUSION}

For members of the community forest to fully participate in forest management, their livelihoods must be taken care of. Members of Kibwezi community forest association received benefits like employment to fence forest, provision of piped water and collecting of soils in the forest for nurseries. Members of community were employed to take care of ecotourism needs and others to protect forest. Some members were employed as casuals while other were employed on permanent basis depending on qualifications an availability of vacancies. The benefits received were too insignificant that most of the members of community forest feels that they are not fully involved due to forest concession.
The management leasehold of dryland forest (lessee) should honour the conditions of leasehold and make sure that CFA get full benefits from conservation. Although forest is fenced, members of CFA should be allowed to benefits by being allowed to get folder, collect firewood, get medicinal herbs from area among other benefits.

\section{CONSENT AND ETHICAL APPROVAL}

All the ethical issues consideration was put into account. These include confidentiality, informed consent, reporting data as whole, seeking necessary authority from Mount Kenya University and National Commission for Science, Technology and Innovation (NACOSTI) among others.

\section{ACKNOWLEDGEMENTS}

I acknowledge further the contributions of my supervisors: Dr. Kweyu Mulaha and Dr. Kagendo Jane, who guided me throughout the study and the Kibwezi community and government officers for their provision of information.

\section{COMPETING INTERESTS}

Authors have declared that no competing interests exist. 


\section{REFERENCES}

1. Ros-Tonena MA, Andelb TV, Morsello C, Otsukid K, Rosendo S, Scholz I. Forestrelated partnerships in Brazilian Amazonia: There is more to sustainable forest management than reduced impact logging. Forest Ecology and Management.2008;16.

2. Pokharel B, Stadtmüller T, Pfund J. From degradation to restoration: An assessment of the enabling conditions for community forestry in Nepal. Natural Resources Management.2010;1.

3. FAO. The State of the World's ForestsForest Pathways to Sustainable Development. Rome; 2018.

4. FAO. Trees, forests and land use in drylands The first global assessment. Rome: FAO;2016.

5. Tadesse S, WoldetsadikM, Senbeta F. Forest Users' level of participation in a participatory forest management program in southwestern Ethiopia. Forest Science and Technology.2017;163-163.

6. Guthiga P, Mburu J. Local communities' incentives for forest conservation: Case of Kakamegaforest in Kenya. $11^{\text {th }}$ Biannual Conference of International Association for the Indonesia: Center for Development Research. 2006;2-29.

7. Newton A, Costillo R, Premoli C, JB, Williums G. Forest Landscape Restoration in the Drylands of LatinAmerica. Ecology and Society. 2012;21.

8. Bircha JC, Newtona AC, Aquinob CA, Cantarelloa E, Echeverríac C. Costeffectiveness of dryland forest restoration. University of Minnesota;2010.

9. MusyokiJK, Mugwe J, Mutundu K, Muchiria M. Factors influencing level of participation of community forest associations in management forests in Kenya. Journal of Sustainable Forestry. 2016;205-216.

10. Newton A, Tejedor N. Principles and Practice of Forest Landscape Restoration; Case studies from the drylands of Latin America. Switzerland: IUCN; 2011.

11. Schiappacasse I, Nahuelhual L, Vásquez $\mathrm{F}$, Echeverría C. Assessing the benefits and costs of dryland forest restoration in central Chile. Journal of Environmental Management.2012;38-45.

12. Francois B, Nora B, Alan G, Danae M The extent of forest. American Association for the Advancement of Science. 2017;635638.

DOI:https://doi.org/10.1126/science.aam65 27

13. Barrow E, Kamugisha-Ruhombe J, Nhantumbo I, Onyano I, Savodogo M. Who owns Africa's Forest? Exploring the Impacts of Forest Tunures Reform on Forest Ecosystem and Livelihood. Forest, Trees and Livelihood. 2016;25(2):132156.

DOI:10.1080/14728028.2016.119999

14. Chirwa $\mathrm{P}$, Larwanou $\mathrm{M}$ Overview of restoration and management practices in the degraded landscapes of the Sahelian and dry land forests and woodlands of East and southern Africa. World Agroforestry Center. 2017;5-15.

15. Bekele M, Bose P, Burger K, Fay P, Kassa $\mathrm{H}$, Kariuki PM, Ingram V. Forests Management and Social Diversity in Africa and Asia. Springer International Publishing Switzerland. 2016;1.

16. Mohammed J, Kofi O-FA, Yusif H. Factors influencing households' participation in forest management in the northern region of Ghana. Independent Journal of Management \& Production.2017;13241340.

17. Koné L. Challenges and opportunities in the adoption of community forestry by local communities and indigenous peoples in the Republic of Congo. International Institute for Environment and Development; 2019.

18. Worku A, Auch E, Pretzsch J, Kassa H The significance of dry forest income for livelihood resilience: The case of pastrolistànd agro-pastrolist in dryland of southern Ethiopia. Forest Policy and Economics. 2014;41:51-59.

DOI:https//doi,org/10.1016/j.forpol.2014.01 .001

19. Bodonirina $\mathrm{N}$, Reibelt LM, Stoudmann $\mathrm{N}$, Chamagne J, Jones TG, Ravaka A, Ramam B. Approaching local perceptions of forest governance and livelihood challenges with companion modeling from a case study around Zahamena National Park, Madagascar. MDPI. 2018; 624.

20. Matiku P, Caleb M, Callistus O. The impact of Participatory forest management on local community livelihood in Arabuko Sokoke forest, Kenya. Conservation and Society.2013;112-129. 
21. GoK. The Forest Conservation and Management Act. Nairobi: Kenya Gazette supppliment; 2016.

22. Elizabeth W, Gilbert O, Bernard K. Social economic Factors that Determine community Partiipation in Forest Management and Conservation of Adjucent Ecosystems: A case of Aberdare Forest, Kenya. Journal of Ecology and Natural Environment. 2017;9(10):165-176. DOI:10.5897/JENE2017.066950

23. Bastin FJ, Berrahmouni N, Grainge A. The extent of forest in dryland biomes. Reports Ecology. 2017;365(6338):635-638.

DOI:10.1126/science.aam6527

24. Kiringe JW, Mwaura F, Warinwa F. Characterization of Chyulu Hills Watershed Ecosystem Services in South-Eastern Kenya. Environment and Natural Resources Research. 2016;6(3).
DOI:10.5539/enrr.v6n3p65

25. Mbuvi T, Ndililo L, Cheboiwa J. Impacts of decentralized governance on forest conservation and community livelihoods in Kakamega and Loita Forests, Kenya. International Intitute for Science, Technology and Education. 2018;8(10).

26. Creswell, Plano C. Designing and Conducting Mixed Methods Research. Thousand Oaks: Sage;2011.

27. Kenya National Bureau of Statistics. Kenya Population Housing Census; Population distribution by administrative units. Nairobi: Government Press. 2009; $1 \mathrm{~A}$.

Retrieved 2018.

28. Mugenda OM, M A. Research Methods: Quantitative and Qualitative Approaches. Nairobi: African Centre for Technology Studies (ACTS) press;2003.

\section{APPENDIX I.MAP OF KIBWEZI FOREST 2018}

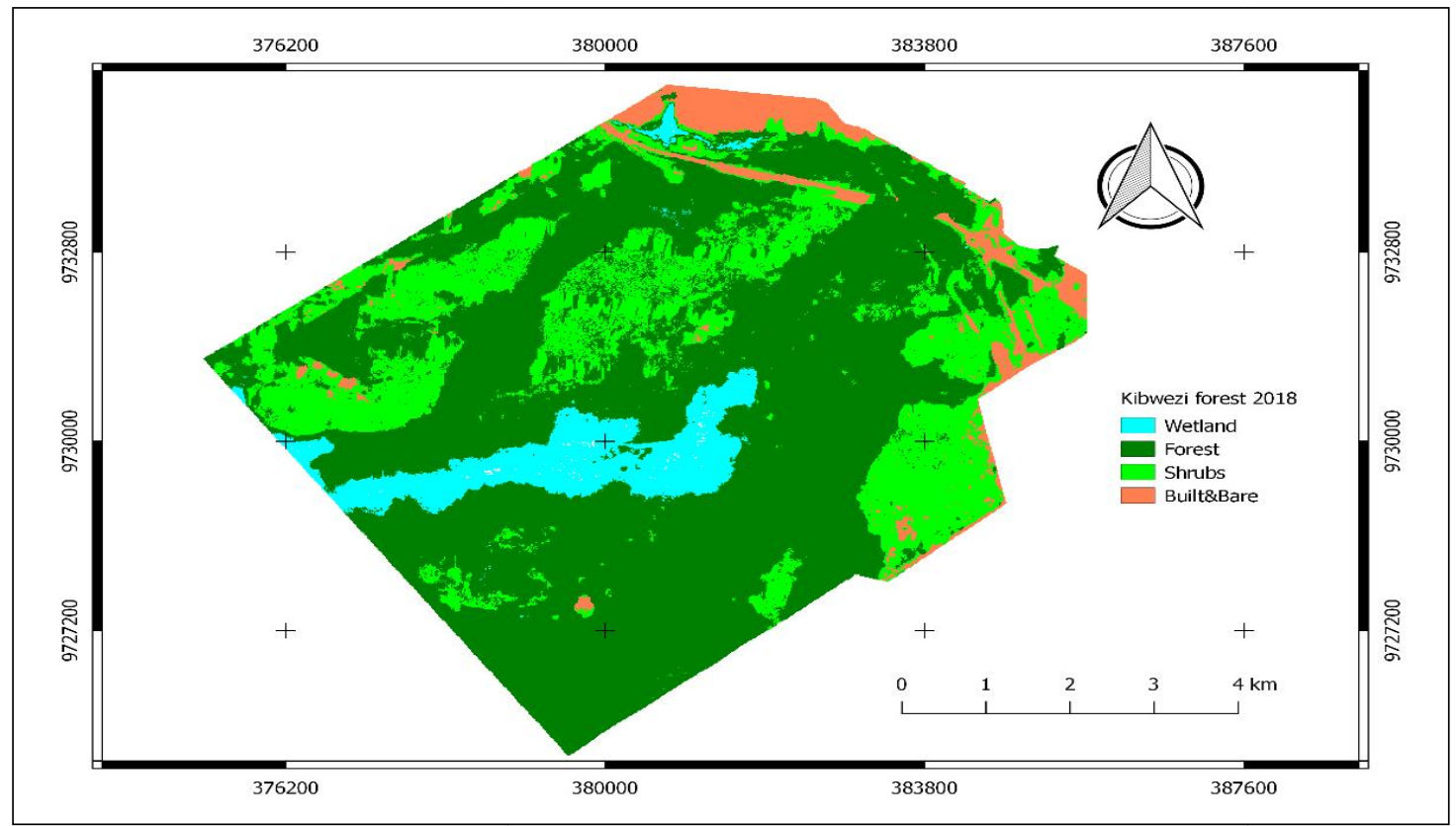

(c) 2020 Mugambi et al.; This is an Open Access article distributed under the terms of the Creative Commons Attribution License (http://creativecommons.org/licenses/by/4.0), which permits unrestricted use, distribution, and reproduction in any medium, provided the original work is properly cited.

Peer-review history:

The peer review history for this paper can be accessed here: http://www.sdiarticle4.com/review-history/58646 